\title{
Phytochemical Screening of Sorghum (Sorghum Sp) with Thin Layer Chromatography Method
}

\author{
Endang Noerhartati ${ }^{1}$, Muhammad Farid Rizal $^{1}$, Elika Joeniarti ${ }^{1}$ \\ ${ }^{1}$ Universitas Wijaya Kusuma Surabaya \\ endang_noer@uwks.ac.id
}

\begin{abstract}
Sorghum is a food plant rich in benefits and has the advantage of being free gluten; it contains antioxidants and has a low glycemic index. The purpose of this research is to determine the content of compounds in sorghum. In the research, the variety of KD 4 sorghum has been used, which was macerated by absolute methanol. Results screening using thin-layer chromatography showed that methanol extract of sorghum contained flavonoid, phenol, triterpenoid, tannin, and saponin compounds, and finally, these compounds will be useful for pharmaceutical products.
\end{abstract}

Keywords: Sorghum, Phytochemical Screening, Thin layer chromatography, Pharmaceutical Products.

\section{INTRODUCTION}

Sorghum is a functional plant that has many benefits for humans, starting from meeting the nutritional needs rich in antioxidants. Sorghum can be used from grains to roots, both in the form of food, cosmetics, or animal feed. Sorghum ranks fifth in the world as a widely cultivated food crop (Noerhartati, Karyati, Soepriyono, \& Yunarko, 2019). The ability of sorghum to adapt to marginal land and requires relatively little water during drought, sorghum is more tolerant than other food crops, making sorghum the top choice for agriculture during the dry season (Musara, Musemwa, Mutenje, Mushunje, \& Pfukwa, 2019). Sorghum seeds have nutritional quality comparable to corn and rice, even with higher protein content and lower fat content (Awika, Rooney, Wu, Prior, \& Cisneros-Zevallos, 2003). During this time, sorghum was also used to add to food and traditional medicine empirically. This makes sorghum has potential as a plant that can be used as a health product ranging from cosmetic ingredients to herbs (Abdu, 2020).

Differences in the place where sorghum grows, such as soil conditions, temperature, light, and climate, can affect the composition of each plant's phytochemical compounds. Keyongan Village, Babat District, Lamongan Regency is a place where the cultivation of Sorghum KD4 Variety. Phytochemical screening aims to find out the compounds contained in KD4 variety sorghum extract from Desa Keyongan. Phytochemical screening using thin-layer chromatography is a simple, fast, and highly selective method that can be used to identify groups of compounds and determine the presence of active compounds contained in plant tissue (Kikowska, Kruszka, Derda, Hadaś, \& Thiem, 2020; Oladeji, Odelade, \& Oloke, 2020).

\section{METHOD}

The method or workflow of this research is as follows: Plant identification was carried out to determine the varieties of sorghum plants cultivated in Keyongan Village, Babat District, Lamongan Regency. The sample used was $0,5 \mathrm{~kg}$ of sorghum grains from Keyongan Village, Babat District, and Lamongan Regency. 
The samples obtained are then ground and then soaked using 3 liters of absolute methanol and then macerated for three days. Then filtered and the macerate got was evaporated with a Rotary evaporator to obtain a thick extract. The method used is thin layer chromatography, phytochemical compound testing methods as follows: Flavonoids: extracts seen in stationary cellulose thin-layer chromatography (TLC) and $15 \%$ mobile phase acetic acid. Detection was carried out with ammonia vapor.

Saponin: extract is sprayed on silica gel F254 plate with ethyl acetate's cellular phase: methanol: water (100: 13.5: 10) V / V with Liebermann Burchard reagents. Tannin: The extract is sprayed on a at a distance of $1 \mathrm{~cm}$ from the bottom edge of the plate with a capillary tube then dried and eluted in various mobile phase ratios, namely ethyl acetate: chloroform: acetic acid (15: 5: 2), n-butanol: acetic acid: water (4: 1: 5), and n-hexane: ethyl acetate (6: 4). Stains formed were examined with UV-Vis lamps at wavelengths of $254 \mathrm{~nm}$ and $66 \mathrm{~nm}$.

Terpenoids: This extract is sprayed on silica gel F254 T25 plates, chloroform: methanol (1: 3) mobile phase, then viewed under $366 \mathrm{~nm}$ UV light and sprayed with 10\% $\mathrm{H} 2 \mathrm{SO} 4$ reagent. Alkaloids: spray extract on silica gel plate F254, n-butanol cellular phase: acetic acid: water (4: 1: 5) $v / \mathrm{v}$ with Dragendof spray reagents. (Hasibuan, Syahfitri, llyas, \& Hutahaean, 2020; Widyaningsih W., Pramono S., 2016).

\section{RESULTS}

Phytochemical screening results of methanol sorghum extract can be seen in the following Table 1. Sorghum is a food substitute for rice that has a comparative advantage over corn, wheat and rice. Sorghum is rich in $73 \%$ carbohydrates, $3.5 \%$ fat, and $10 \%$ protein, depending on the variety and location of planting ( $\mathrm{Li}$, Jeong, Lee, \& Chung, 2020).

Table 1. Phytochemicals Screening of Sorghum KD 4 Variety.

\begin{tabular}{lll}
\hline $\begin{array}{l}\text { Secondary } \\
\text { metabolites }\end{array}$ & $\begin{array}{l}\text { Color spots on Thin Layer } \\
\text { Chromatography Plates }\end{array}$ & Result \\
\hline Flavonoid & Blue light & $(+)$ \\
Triterpenoid & Violet & $(+)$ \\
Tannin & Black & $(+)$ \\
Saponin & Tawny & $(+)$ \\
Fenol & Blue & $(+)$ \\
\hline \multicolumn{2}{l}{ Description: Positive $(+)$} \\
\\
\multicolumn{2}{l}{ Negative $(-)$}
\end{tabular}

The development of sorghum as a food crop through product diversification makes the potential of sorghum as an herbal medicinal plant that has pharmacological effects. To be used as raw material for herbal medicines, standardization needs to be done. One of the parameters for standardization of traditional medicinal ingredients is information about secondary metabolites and the profile of this plant extract using thin layer chromatography (TLC) (Raj, 2020). 
Phytochemical screening is conducted to determine secondary metabolites found in sorghum, as the initial stage of processing pharmaceutical products. Extraction is done by maceration method to attract substances in tissues to sorghum cells, the advantage of this method is that it only requires fat solvents for example, ethanol or methanol to soak and produce good extract products, besides this technique does not damage the active compounds caused by warming (Makuasa \& Ningsih, 2020).

The results of phytochemical screening can be seen in Table 1. The sorghum methanol extract in the TLC test proved the presence of compounds, phenols, triterpenoids, flavonoids, tannins, and saponins.

Flavonoid test results on sorghum methanol extract showed positive results with bright blue spots on TLC plates. Flavonoids are secondary metabolites that are most often found in plant structures. Some research results show that there is a negative correlation between flavonoid intake and risk of coronary heart disease. The cardioprotective effect of flavonoids as a food source in addition to the cardioprotective properties of flavonoids which have antiproliferation properties against cancer cells (Ayza, Balasubramanian, \& Berhe, 2020; Ferenczyova, Kalocayova, \& Bartekova, 2020) and have antioxidant, antiparasitic and anti-bacterial roles. Because of its antioxidant properties, flavonoids are often added in cosmetics because of their antibacterial properties (Herlina, Rudiana, Julaeha, \& Parubak, 2019; Mead \& McNair, 2006).

Triterpenoid test results with TLC showed positive results by marking a purple dot on the TLC plate. Triterpenoids in the health world are used as antioxidants, besides that triterpenoids have immunomodulating and anti-tumor activity (Giuberti, Marti, Gallo, Grassi, \& Spigno, 2019). Triterpenoids have inflammatory, antidepressant, protective properties on brain cells. Several structural groups of triterpenoids have shown specificity in transcription factors which can be promising candidates for treating inflammation, cancer, and immune disease (Sadaq, Seetharamaiah, Pamar, \& Mehar, 2013).

Tannin test results with TLC showed positive results in the presence of black stains on the TLC plates. Tannin is a compound found in most plants, tannin has a function as a chelating protein, chelator properties make tannin can be used as a chelator to heavy metals in the microbiology world, tannins have the activity of inhibiting protein synthesis in bacterial cells so tannins are often used as astrigence and have high antioxidant ability as free antiradical (Ashok \& Upadhyaya, 2012).

Saponin test results with TLC showed positive results in the presence of brownish stains on the TLC plates. The presence of saponins in plants is often characterized by the presence of foam in plants. Saponin is often used as an antiseptic such as soap because of its very strong antibacterial properties (Ngajowa et al 2013). Saponins are also often used as anticancer because of their cytotoxic activity against cancer cells (Aboutalebi \& Monfared, 2016; Podolak, Galanty, \& Sobolewska, 2010).

The phenol test results showed a light blue color on the TLC plates which indicated that sorghum extract contained phenolic groups. phenols are compounds that have high antioxidant activity and function to reduce reactive oxygen species. phenol can be used as a prevention or treatment for diseases caused by oxidative stress. Besides that, phenol also has a strong antibacterial function, especially against gram-positive bacteria (Fu et al., 2010; Ravanfar, Karimi, Mehrabanjoubani, \& Ebrahimi, 2020). 
TLC results of KD 4 sorghum seed varieties contain phytochemicals which have been instrumental in the treatment of various diseases, in this case sorghum seeds have potential as medicinal plants which can be developed into various pharmaceutical products.

\section{CONCLUSIONS}

Based on the results of this study it can be concluded that extracts from KD 4 sorghum seeds contain phytochemical contents as follows: Flavonoids, tannins, triterpenoids, saponins, and phenols. Sorghum methanol extract has potential as a pharmaceutical product. The results obtained from the research have to be supported by sufficient data. The research results and the discovery must be the answers, or the research hypothesis stated previously in the introduction part.

\section{REFERENCES}

Abdu, H. H. (2020). Phytochemical screening and antibacterial activities of Sorghum bicolor leaves derived from in vitro culture. GSC Biological and Pharmaceutical Sciences, 10(1), 65-72.

Aboutalebi, R., \& Monfared, A. (2016). Saponin Terpenoids; A brief review of mechanisms of actions and anti-cancerous effects. Chemical Science International Journal, 1-8.

Ashok, P. K., \& Upadhyaya, K. (2012). Tannins are astringent. Journal of Pharmacognosy and Phytochemistry, 1(3), 45-50.

Awika, J. M., Rooney, L. W., Wu, X., Prior, R. L., \& Cisneros-Zevallos, L. (2003). Screening methods to measure antioxidant activity of sorghum (Sorghum bicolor) and sorghum products. Journal of Agricultural and Food Chemistry, 51(23), 6657-6662.

Ayza, M. A., Balasubramanian, R., \& Berhe, A. H. (2020). Cardioprotective effect of Croton macrostachyus stem bark extract and solvent fractions on cyclophosphamide-induced cardiotoxicity in rats. Evidence-Based Complementary and Alternative Medicine, 2020.

Ferenczyova, K., Kalocayova, B., \& Bartekova, M. (2020). Potential Implications of Quercetin and its Derivatives in Cardioprotection. International Journal of Molecular Sciences, 21(5), 1585.

Fu, L., Xu, B.-T., Xu, X.-R., Qin, X.-S., Gan, R.-Y., \& Li, H.-B. (2010). Antioxidant capacities and total phenolic contents of 56 wild fruits from South China. Molecules, 15(12), 8602-8617.

Giuberti, G., Marti, A., Gallo, A., Grassi, S., \& Spigno, G. (2019). Resistant starch from isolated white sorghum starch: functional and physicochemical properties and resistant starch retention after cooking. A comparative study. Starch-Stärke, 71(7-8), 1800194.

Hasibuan, F. E., Syahfitri, W., llyas, S., \& Hutahaean, S. (2020). Phytochemical screening, antioxidant activity and thin-layer chromatography test of methanol extract and simplicia leaves of loquat (Eriobotrya japonica Lindl). In IOP Conference Series: Materials Science and Engineering (Vol. 725, p. 12069). IOP Publishing.

Herlina, T., Rudiana, T., Julaeha, E., \& Parubak, A. S. (2019). Flavonoids from stem bark of akway (Drymis beccariana Gibs) and theirs antimalarial properties. In Journal of Physics: Conference Series (Vol. 1280, p. 22010). IOP Publishing.

Kikowska, M., Kruszka, D., Derda, M., Hadaś, E., \& Thiem, B. (2020). Phytochemical Screening and Acanthamoebic Activity of Shoots from in Vitro Cultures and in Vivo Plants of Eryngium alpinum L.-The Endangered and Protected Species. Molecules, 25(6), 1416.

Li, C., Jeong, D., Lee, J. H., \& Chung, H.-J. (2020). Influence of germination on physicochemical properties of flours from brown rice, oat, sorghum, and millet. FOOD SCIENCE AND BIOTECHNOLOGY.

Makuasa, D. A. A., \& Ningsih, P. (2020). The Analysis of Total Flavonoid Levels In Young Leaves and Old Soursop Leaves (Annona muricata L.) Using UV-Vis Sepctrofotometry Methods. Journal of Applied Science, Engineering, Technology, and Education, 2(1), 11-17.

Mead, J. R., \& McNair, N. (2006). Antiparasitic activity of flavonoids and isoflavones against Cryptosporidium parvum and Encephalitozoon intestinalis. FEMS Microbiology Letters, 259(1), 153-157.

Musara, J. P., Musemwa, L., Mutenje, M., Mushunje, A., \& Pfukwa, C. (2019). Determinants of sorghum adoption and land allocation intensity in the smallholder sector of semi-arid Zimbabwe. Spanish Journal of 
Agricultural Research, 17(1), 105.

Noerhartati, E., Karyati, P. D., Soepriyono, S., \& Yunarko, B. (2019). Entrepreneurship Sorghum towards Industry 4.0. In International Conference on Innovation in Research (ICIIR 2018)-Section: Economics and Management Science. Atlantis Press.

Oladeji, O. S., Odelade, K. A., \& Oloke, J. K. (2020). Phytochemical screening and antimicrobial investigation of Moringa oleifera leaf extracts. African Journal of Science, Technology, Innovation and Development, 12(1), 79-84.

Podolak, I., Galanty, A., \& Sobolewska, D. (2010). Saponins as cytotoxic agents: a review. Phytochemistry Reviews, 9(3), 425-474.

Raj, D. (2020). Thin-Layer Chromatography With Eutectic Mobile Phases-Preliminary Results. Journal of Chromatography A, 461044.

Ravanfar, S. A., Karimi, E., Mehrabanjoubani, P., \& Ebrahimi, M. (2020). Enhancement of phenolic and flavonoids compounds, antioxidant and cytotoxic effects in regenerated red cabbage by application of Zeatin. Natural Product Research, 34(6), 898-902.

Sadaq, S. I., Seetharamaiah, N., Pamar, J. D., \& Mehar, A. (2013). Characterization and mechanical behavior of composite material using FEA. International Journal of Engineering Research, 2(2), 125-131.

Widyaningsih W., Pramono S., W. and S. (2016). Phytochemical Screening Of Ethanolic Extract From Ulva lactuca I. with thin layer chromatography. Pharmaceutical Media, 13(2).

(C) 2020 by the authors. Submitted for possible open access publication under the terms and conditions of the Creative Commons Attribution (CC BY SA) license (https://creativecommons.org/licenses/by-sa/3.0/). 